\title{
Article
}

\section{Prescribing exam practice questions}

Davies, Janice Anne

Available at http://clok.uclan.ac.uk/21859/

Davies, Janice Anne (2018) Prescribing exam practice questions. Nurse Prescribing, 16 (3). pp. 112-114. ISSN 2052-2924

It is advisable to refer to the publisher's version if you intend to cite from the work.

10.12968/npre.2018.16.3.112

For more information about UCLan's research in this area go to

http://www.uclan.ac.uk/researchgroups/ and search for < name of research Group>.

For information about Research generally at UCLan please go to http://www.uclan.ac.uk/research/

All outputs in CLoK are protected by Intellectual Property Rights law, including Copyright law. Copyright, IPR and Moral Rights for the works on this site are retained by the individual authors and/or other copyright owners. Terms and conditions for use of this material are defined in the policies page.

\section{CLoK}

Central Lancashire online Knowledge www.clok.uclan.ac.uk 
Many nurses will be taking their prescribing exam this year.

It is a requirement of the Nursing and Midwifery Council (NMC) that nurses complete a numeracy assessment in order to gain the prescribing qualification. The numeracy assessment is related to prescribing and calculations regarding medicines and must be passed with a score of $100 \%$.

The actual numeracy assessment varies across Universities, for example, some may be multiple choice questions carried out on a computer whereas as some may require handwritten answers on the exam paper. Many allow students to use calculators but the answer should always be checked with a measure of common sense to reduce the risk of inputting errors on the calculator eg pressing digits twice.

Typically, there will be 5 questions to test nurses' ability to perform a range of calculations, such as:

Change units eg nanograms to micrograms to milligrams to grams to kilograms and vice versa.

Calculate how many tablets to give per dose / day / course / month.

Calculate the cost per prescription / month / year.

Calculate the patient's dose where the dosage is based on weight eg $\mathrm{mg} / \mathrm{kg}$.

Calculate what volume of liquid to prescribe where you have already calculated the required dose in milligrams.

Calculate the percentage dose reduction, for example in renal or liver impairment.

These exercises provide some extra practice for those undertaking the exam. These are also useful for anyone who wants to test their calculation skills. Extra practice can also be gained using SN@P at https://snap-services.org/education/index.php (free but registration is required) or for a more basic refresher of GCSE level maths BBC Bitesize is useful at https://www.bbc.com/education/examspecs/z8sg6fr

Converting units

1. Express $1000 \mathrm{mg}$ in grams

2. Express 500 microgram in milligrams. $0.5 \mathrm{mg}$

3. Express $0.25 \mathrm{mg}$ in micrograms. 250 micrograms

4. A depot injection contains $150 \mathrm{mg} / 1 \mathrm{ml}$ of drug A. How much of drug A does $1 \mathrm{ml}$ depot contain in grams?

$0.15 \mathrm{~g}$

Calculating total quantity 
5. Your patient requires a daily dose of 300 milligrams of Drug B. Tablets are available in 75 milligrams. How many tablets should the patient take each day?

6. The dose of Drug $C$ is $1 \mathrm{mg}$ bd. Drug $C$ is only available as 250 microgram tablets. How many tablets should be prescribed for 7 days treatment?

56 tablets

7. A patient is prescribed Drug $D$ inhaler, to take two puffs twice a day. The inhaler contains 100 doses. How many days should the inhaler last if the patient is using it as prescribed?

25 days

8. Your patient requires treatment of 28 days duration and the recommended dose of Drug $E$ is 1 gram twice daily. Drug $E$ is only available as $250 \mathrm{mg}$ tablets. How many tablets should be prescribed? 224

9. A patient uses an inhaler of Drug F, two metered inhalations twice a day. The inhaler strength is 500 micrograms per metered inhalation. Assume good compliance and good inhaler technique. How much of Drug $\mathrm{F}$ does the patient inhale each day in milligrams?

$2 \mathrm{mg}$

10. Drug $\mathrm{G}$ is to be given as an intravenous infusion at a rate of $6 \mathrm{mg} /$ hour. How many milligrams would have been given after 4 hours? $\quad 24 \mathrm{mg}$

11. Your patient has been prescribed 7 days of triple therapy for H.pylori eradication, which is a combination of:

Drug $\mathrm{H} 30 \mathrm{mg}$ twice a day Drug $\mathrm{J} 1 \mathrm{~g}$ twice a day

Drug K 500 $\mathrm{mg}$ twice a day.

Drug $\mathrm{H}$ is a $30 \mathrm{mg}$ capsule. Drug $\mathrm{J}$ is only available as $500 \mathrm{mg}$ capsules.

Drug $\mathrm{K}$ is a $500 \mathrm{mg}$ tablet. Assuming full compliance, how many tablets/capsules in total must the patient take over 7 days to complete the course?

56

Calculating cost

12. One pack of 28 tablets of Drug L costs $£ 33$. How much would one year's supply cost? Assume 12 packs per year. $\quad £ 396$

Weight based dosage

13. Your patient needs Drug M. The BNF suggests a dose of $750 \mathrm{mg} / \mathrm{kg}$ daily. The patient weighs $12 \mathrm{~kg}$. How much of drug M should be prescribed daily in grams?

$9 g$

14. A dose of $7.5 \mathrm{mg} / \mathrm{kg}$ is needed to treat your patient who weighs $80 \mathrm{~kg}$. What dose does the patient require?

$600 \mathrm{mg}$

Calculating volume of liquid 
15. You decide that your patient needs 5 days treatment of Drug $N$, at a dosage of 500 $\mathrm{mg}$ three times per day. Drug $\mathrm{N}$ is available as a suspension of $50 \mathrm{mg} / \mathrm{ml}$. What volume of suspension, in millilitres, should be prescribed for the 5 days treatment? $150 \mathrm{ml}$

16. You wish to prescribe Drug $P$ for your patient. The recommended daily dose is 50 micrograms $/ \mathrm{kg}$. Your patient weighs $60 \mathrm{~kg}$. Drug $P$ is available as a liquid, and the strength is $1 \mathrm{mg} / 5 \mathrm{ml}$. How many millilitres should be given each day? $15 \mathrm{ml}$

17. You wish to give Drug $Q$ to a patient who weighs $25 \mathrm{~kg}$. The BNF suggests a dose of $8 \mathrm{mg} / \mathrm{kg}$ daily. Drug Q is available as suspension of $100 \mathrm{mg} / 5 \mathrm{ml}$. What volume of suspension is needed for each daily dose? $\quad 10 \mathrm{mls}$

18. Your patient needs a daily dose of $2 \mathrm{mg}$ of Drug $\mathrm{R}$. Drug $\mathrm{R}$ is only available in 250 micrograms $/ 5 \mathrm{ml}$ liquid doses. What volume of Drug $R$ liquid in millilitres should the patient take each day? $40 \mathrm{ml}$

19. Your patient needs a daily dose of $500 \mathrm{mg}$ of Drug S. Drug $S$ is only available in $1 \mathrm{~g} / 5 \mathrm{ml}$ liquid doses. How much liquid in millilitres should the patient take each day? $2.5 \mathrm{ml}$

20. A baby needs to take $62.5 \mathrm{mg}$ of drug $\mathrm{T}$ three times a day for 5 days. Drug $\mathrm{T}$ is only available in $125 \mathrm{mg} / 5 \mathrm{ml}$ liquid. What total volume of drug T should be prescribed? $37.5 \mathrm{ml}$

Calculating percentage dose reduction

21. You are prescribing for a patient with liver disease and the manufacturer directs you to initiate treatment at $60 \%$ of the usual adult dose. The usual adult dose of Drug $U$ is $500 \mathrm{mg}$ daily? What daily dose of Drug $U$ should be initiated for this patient?

$$
300 \mathrm{mg}
$$

22. The usual adult dose of drug $V$ is $200 \mathrm{mg}$ daily. The dose needs to be reduced to $25 \%$ of the usual dose in renal impairment. What dose should be prescribed in a patient with renal impairment

$50 \mathrm{mg}$

23. The manufacturer of drug $\mathrm{W}$ recommends prescribing $25 \%$ less than the usual dose in elderly patients. The usual dose is $200 \mathrm{mg}$ daily. How much should you prescribe for your elderly patient? $150 \mathrm{mg}$ 